\title{
THE CONTRIBUTION OF THE NOVELS TRANSLATED INTO OTTOMAN TURKISH BETWEEN THE OTTOMAN TANZIMAT PERIOD AND THE ALPHABET REFORM TO THE OTTOMAN/TURKISH CULTURAL HERITAGE: AN OVERVIEW OF THE PREFACES WITH A FOCUS ON NATIONAL MORALS AND CUSTOMS
}

\author{
Ayşe Banu KARADAĞ $\breve{~}^{1}$
}

\begin{abstract}
This article aims to investigate the effects of the Ottoman/Turkish morals and customs on the selection of novels to be translated from Western languages into Ottoman Turkish and the translation strategies deployed by the translators between the Tanzimat Period and the Alphabet Reform in witness of the prefaces written by the translators and publishers of the period. The novel, as a literary genre, entered the Ottoman/Turkish literary system in the Tanzimat Period and a high number of translated and original novels were produced in the historical period examined in the present study. Conformity of the content of the works with the Ottoman/Turkish morals and customs emerges as a major issue in the context of the translations in question. In terms of preliminary and operational norms (Gideon Toury), translators and/or publishers either viewed the content-related conformity as a criterion in selecting works for translation or they decided to change or omit the parts in the source texts that they considered inappropriate for the Ottoman/Turkish "national morals" (âdât-ı millî) and Islamic morals. While some translators were sensitive about the Turkish language, some others were specifically concerned about the material and spiritual characteristics of the Turks and the Turkish authors. In the present study, the forewords and afterwords by the translators and publishers will be discussed in relation to the memoirs of the translators and publishers. Moreover, the emphasis on the "idea of nationality" (millîlik) and the "cultural repertoire" (Itamar Even-Zohar) desired to be created accordingly by the translators and publishers will be examined via the analysis of a selected corpus of forewords and afterwords. The results of the examination will be evaluated in the context of contemporary theories of translation with the aim of shedding light on the function of the activity of translation -defined as a means of intercultural communication and interaction- in the context of Turkish nationalism in the relevant historical period.
\end{abstract}

Keywords: The Tanzimat Period, Cultural Heritage, Translated Novel, Turkish Nationalism, Culture Repertoire.

\section{TANZIMAT'TAN HARF DEVRIMMINE KADAR OSMANLI TÜRKÇESINE ÇEVRİLEN ROMANLARIN KÜLTÜREL MİRASIMIZA KATKISI: MİLLÎ AHLAK VE ÂDET VURGUSUYLA MUKADDIMELERE GENEL BİR BAKIŞ}

\section{Özet}

Bu makalede, Tanzimat'tan Harf Devrimi’ne kadar Batı dillerinden Osmanlı Türkçesine çevrilen romanlarda, Türk millî ahlak ve âdetlerinin gerek çevrilecek eser seçimi gerekse çeviri yöntemleri üzerindeki etkilerinin çevirmen ve yayıncı tanıklı̆̆ında araştırılması amaçlanmaktadır. Türk kültür ve edebiyat dizgesine çeviri yoluyla giren ve ilk örneklerine Tanzimat Dönemi'nde rastlanan roman türünde belirtilen dönemler arasında çeviri ve telif birçok eser verildiği görülmektedir. Bu çevirilerde birtakım özellikler göze çarpmaktadır. Bunlardan birisi, eserin muhtevasının Türk ahlak ve âdetlerine uygunluğu mevzusudur. Süreç-öncesi çeviri ve çeviri süreci normları bağlamında (Gideon Toury), çevirmenler ve/veya yayıncılar, bazen eser seçiminde bunu göz önünde bulundurmuş bazen de çeviri 
The Contribution of the Novels Translated into Ottoman Turkish Between the Ottoman Tanzimat Period and the Alphabet Reform to the Ottoman/Turkısh Cultural Heritage: An Overview of the Prefaces with a Focus on National Morals and Customs / A. Banu Karadağ (113-128. p.)

sırasında Türk “âdât-ı millı̀”sine ve “İslam ahlakı”na uygun olmayan yerleri değiştirmeyi ya da çıkarmayı uygun görmüşlerdir. Kimi çevirmenler Türk dili konusuna ayrı bir hassasiyet göstermiş kimisi de Türk yazarlarını ve Türklerin maddi manevi birçok özelliğini ön plana çıkarmıştır. Makalede çevirmen ve yayıncı ön söz ve son sözleri, ilgili çevirmen ve yazar hatıralarıyla bağlantılandırılacak ve çevirmen ve yayıncıların Türk çeviri edebiyat dizgesinde "millîlik" vurgusuyla ne tür bir "kültür repertuarı" (Itamar Even-Zohar) oluşturmak istedikleri çeviri metinlerin ön söz/son söz örnekleriyle irdelenecektir. İrdelemede ortaya çıkan sonuçlar, kültürlerarası iletişim ve etkileşim aracı olarak görülen çeviri eyleminin ilgili dönemde Türk milliyetçiliği odağıyla ne tür bir işlev üstlendiğine ışık tutacak şekilde çă̆daş çeviribilim kuramları çerçevesinde değerlendirilecektir.

Anahtar Kelimeler: Tanzimat Dönemi, Kültürel Miras, Çeviri Roman, Türk Milliyetçiliği, Kültür Repertuarı.

\section{Introduction}

Novel entered the Ottoman/Turkish system as a literary form for the first time in the Tanzimat period via translation. Considered to be a genre particular to the Western culture until then, novel enjoyed great popularity in a short time and hundreds of translated and original novels were offered to the Turkish reader. Approximately one thousand two hundred novels were translated into Ottoman Turkish between the Tanzimat Period and the Alphabet Reform. Between the Tanzimat Period and the Second Constitutional Period, approximately five hundred twenty novels were translated and seven hundred and thirteen novels were translated between the Second Constitutional Period and the Alphabet Reform. It should be noted that these figures obtained by scanning the Özege Catalogue are considerably high even though they refer only to the translated novels, which displays the extent of the demand for translated novels in the relevant period. Translated novels played an important role in the translated literary system of the Turkish literary and cultural polysystem by contributing to the "making" of a "culture repertoire" with a special emphasis on "national morals and customs". Within the context of "polysystem theory" by Itamar Even-Zohar, the "culture repertoire" is defined as "the aggregate or the accepted stock of options utilized by a group of people, and by its individual members, for the organization of life" (Even-Zohar, 2002: 166). According to EvenZohar, "translated works do correlate in at least two ways: (a) in the way their source texts are selected by the target literature, the principles of selection never being uncorrelatable with the home co-systems of the target literature (to put it in the most cautious way); and (b) in the way they adopt specific norms, behaviors, and policies -in short, in their use of the literary repertoire -which results from their relations with the other home co-systems" (Even-Zohar, 2000: 192-193).

There is no doubt that translations are facts of the target culture and thus "translation activities should rather be regarded as having cultural significance" (Toury, 1995: 54). Gideon Toury makes use of the concept of "norm" from sociology and defines it as "the translation of general values or ideas shared by a community -as to what is right and wrong, adequate and inadequate- into performance instructions appropriate for and applicable to particular situations, specifying what is prescribed and forbidden as well as what is tolerated and permitted in a certain behavioural dimension". People acquire norms during their socialization process; that's why they "always imply sanctions -actual or potential, negative as well as positive" (a.g.e., 55).

Norms operate at every stage of translation activity. "Preliminary norms" have two main sets of considerations: "translation policy" and "directness of translation":

"Translation policy refers to those factors that govern the choice of text-types, or even of individual texts, to be imported through translation into a particular culture/language at a particular point in time. Such a policy will be said to exist in as much as the choice is found 
Tanzimat’tan Harf Devrimine Kadar Osmanlı Türkçesine Çevrilen Romanların Kültürel Mirasımıza Katkısı: Millî Ahlâk ve Âdet Vurgusuyla Mukaddimelere Genel Bir Bakış / A. Banu Karadağ (113-128. s.)

to be nonrandom." [...] Considerations concerning directness of translation involve the threshold of tolerance for translating from languages other than the ultimate source language [...]" (a.g.e., 58$)$.

It can be also useful to mention Toury's operational norms to analyse translators' decisions made during the act of translation itself. According to Toury, "matricial norms" "affect the matrix of the text -i.e., the modes of distributing linguistic material in it- as well as the textual make-up and verbal formulation as such" and "textual-linguistic norms, in turn, govern the selection of material to formulate the target text in, or replace the original textual and linguistic material with" (a.g.e., 59).

As a new genre in the Turkish literary system in the Tanzimat Period, novel was regarded as a harmful literary form by some while others regarded it as an instrument to provide readers with knowledge/services. Fatih Andı argues that besides the aesthetic effect, literary works have the functions of transferring knowledge, raising awareness and awakening, and that novel is one of the genres that realizes such an effect in the most intense and easy manner and thus creates suspicion (Andı, 1999: 7). Andı explains the said perception of novel as follows:

\begin{abstract}
"Novel was introduced to the Turkish society in the 19th century. However, this acquaintance had always been accompanied by a sense of suspicion and had not been transformed into a true familiarity and integration. Most of the time, novel had been an objectionable literary genre and a seditious, harmful tool for people and the lay reader. [....] Novel may provide the members of the society with alternative and "ideal" ways of life and broaden their horizon within an imaginary and soft atmosphere and without imposing any restrictions. The majority of the readers put themselves in the shoes of protagonists and unwittingly "live the novel" within the limitless boundaries of imagination. [...] Thus, the reader gets influenced and this is precisely what causes the lay reader to think that novel is a seditious literary product. For the parents who observe that their children are transformed into individuals completely different from them, the harmful effect of novel is no longer a suspicion but a reality" (Andı, 1999: 15-16).
\end{abstract}

As seen in the statements by the translators of the period, novel was perceived as a means and certain functions were attributed to this literary genre. In addition, it may be argued that certains functions were also allotted to translators of the period in question. This reminds us Toury's concept of "translatorship". According to Toury "translatorship amounts first and foremost to being able to play a social role, i.e., to fulfill a function allotted by a community to the activity, its practitioners and/or their products- in a way which is deemed appropriate in its own terms of reference. The acquisition of a set of norms for determining the suitability of that kind of behaviour, and for manoeuvring between all the factors which may constrain it, is therefore a prerequisite for becoming a translator within a cultural environment" (Toury, 1995: 53).

Accordingly, one major function of the novel concerned the issues of "exemplary case" and "morality". In the foreword titled "Our Statement" written by Halil Edib and Ali Riza for the novel they jointly translated, 13 Numaral Araba by Xavier de Montépin (1307 [1889]), the translators stated that the greatest service to humanity was to present to the readers the events taking place among people as a story (Trans. Halil Edib and Ali Riza, 1307 [1889], Foreword). Another translator with a similar approach was Bogos who, in the foreword for his translation of Son Assk by Georges Ohnet (1305 [1887]: 3), drew attention to exemplary cases and morality as well as the entertaining function of the novel and claimed that one peculiar feature of the novel was to enhance morality.

\title{
2. Turkish Nationalism in the Witness of Translators and Publishers
}

Translators and publishers discussed a variety of issues in the forewords and afterwords they penned for the novels they translated. Examination of these forewords and afterwords reveals 
The Contribution of the Novels Translated into Ottoman Turkish Between the Ottoman Tanzimat Period and the Alphabet Reform to the Ottoman/Turkısh Cultural Heritage: An Overview of the Prefaces with a Focus on National Morals and Customs / A. Banu Karadağ (113-128. p.)

that besides the cases where novels were defined as useless, even harmful, there were translators and publishers who viewed the novel as a literary form that could be utilized as an educational tool especially in the field of morals. Translators and publishers considered certain criteria in selecting texts to be translated and created a culture repertoire in accordance with the policies they adopted. One such point considered and highlighted in the forewords and afterwords by the translators and publishers concerned the idea of Turkish nationalism, which validates the claim by Andı with regard to the "raising awareness and awakening" functions of the novel (1999: 7).

The roots of Turkish nationalism are traced back to old. In Avrupa Edebiyat ve Biz Garpten Tercümeler (1940-1941, 2 volumes), İsmail Habib Sevük suggests that Turkism was manifest in three fields of "language, history and race" and was defended by the Turcologists starting from the 11th century (Sevük, 1941: 591). Among the Turcologists cited by Sevük are important translators of the Tanzimat and Constitutional Periods such as Şemseddin Sâmi and Necib Asım. Sevük divides the Turkism of the Oppression Period into two phases: "scientific Turkism" and "literary Turkism," and positions Necib Asım in the first group. Some translators and publishers such as Necib Asım tried to raise consciousness about Turkish nationalism by ascribing a specific function to novel as a literary genre. This form of Turkish nationalism, about which the translators and publishers tried to raise consciousness, can be divided into and examined via the following sub-categories in accordance with the issues discussed in the forewords and afterwords: nationalism in relation to the Turkish language, nationalism in relation to the Turkish customs and morals, nationalism in relation to Turkish writers, nationalism in relation to national resources, and nationalism in relation to the names of protagonists and themes.

\subsection{Nationalism in Relation to the Turkish Language}

Some translators attributed special importance to the Turkish language in translation and were meticulous in this regard. There were even translators who despised the Western languages. Such a translator was Ali Kemal who translated Yeni Kadın Mektuplar by Marcel Prévost (1330 [1914]) and wrote two lengthy forewords titled "A Foreword, One More Foreword" and an afterword titled "Epilogue" for the translation where he displayed his sensitivity about the Turkish language and called the wording used in Western languages "wild" (See Endnote 1 and Appendix 1).

According to Ali Kemal, when translating from Western languages, the potential possibilities of the Turkish language should be expanded to render some expressions and while it was acceptable to benefit from Arabic and Persian, the wild wording of the "foreign" should be avoided. However, it should be noted that Kemal did not support borrowing all the words from Arabic and Persian and regarded that kind of a strategy as a betrayal of "Ottomanness" and the destruction of literary treasures. In his view, an Arabic or Persian word would not harm and strengthen the Turkish language only if the word entered the language in a useful and effective way (See Endnote 2 and Appendix 1).

Another foreword where Kemal provided the readers with his views on the Turkish language in more detail was the foreword titled "Kâri'în-i Kirâma" written by the translator for Jülyet'in İzdivace (1315 [1897]) by Marcel Prévost. In this foreword, Kemal criticized some translators for their carelessness and incompetence regarding their native language. He accused the translators of being "unelaborate", offered certain instructions and advised them first to master in their native language and then in Western languages so that their efforts would not be wasted. According to Kemal, language was as sacred as one's mother, father and homeland (See Endnote 3 and Appendix 2).

Ahmed Midhat Efendi, one of the leading translators of the Tanzimat Period, also adopted a stance that protected the Turkish language in the context of translation. In the foreword titled 
Tanzimat’tan Harf Devrimine Kadar Osmanlı Türkçesine Çevrilen Romanların Kültürel Mirasımıza Katkısı: Millî Ahlâk ve Âdet Vurgusuyla Mukaddimelere Genel Bir Bakış / A. Banu Karadağ (113-128. s.)

"İfade-i Mütercim" he wrote for his translation Bir Fakir Delikanlının Hikâyesi (1298 [188o]) by Octave Feuillet, he mentioned that he did not do a "literal" translation on the grounds that every language had a specific idiom and thus a "literal" translation would add a "Western scent" to the translated novel (Trans. Ahmed Midhat Efendi 1298 [1880]: Foreword). Ahmet Midhat Efendi emphasized the same approach in the foreword he wrote for another translation Nedâmet mi? Heyhât! (1306 [1888]) (See Endnote 4 and Appendix 3).

Thus, Ahmed Midhat Efendi believed that the language of translation should sound as a native language. The sensitivity about the Turkish language was also shared by other translators such as Iskender Ferari and Müstecâbî-zâde İsmet who declared that they were extremely careful about conformity with the "idiom of the language" in the foreword titled "Our Statement" they wrote for Lamartine's Rafael (1316 [1898]) they jointly translated (Trans. İskender Ferari ve Müstecâbî-zâde İsmet 1316 [1898]: Foreword).

\subsection{Nationalism in Relation to Turkish Customs and Morals}

The statements by the translators of the period in question reveal that the translators made some changes in the novels they translated such as changing or omitting a certain part of the source text on the grounds that Western writers penned their novels in the Western culture for the Western society and thus certain parts of the novels were not appropriate for the Turkish and Islamic morals.

Among the translators who adopted a nationalist stance, Ahmed İhsan was a leading figure. In his foreword titled "Statement" for his translation of Jules Verne's Yeraltında Seyahat (1308 [1890]), İhsan regarded the novels with an entirely Western base as incongruous with Islamic morals and national customs (See Endnote 5 and Appendix 4).

Another translator who shared the same opinion with Ahmed İhsan was Mazhar. In the foreword titled "Statement" he wrote for his translation of Jules Verne's Arzdan Kamere Seyahat (1309 [1891]), Mazhar stated that science was beneficial for all nations but the national customs of a nation might not be beneficial for each and every nation. He furthermore argued that customs of one nation might even poison other nations in terms of morality and presented this view as the reason underlying his decision to translate scientific novels. $\mathrm{He}$ explained that he preferred to translate the Jules Verne novel since it was free of harmful content such as bad habits and moral defects, and the novel enlightened the Ottoman world of thought (See Endnote 6 and Appendix 5).

Yusuf Neyyir, who translated Lamartine's Graziella (1296 [1878]), agreed with Ahmed İhsan and Mazhar. In the foreword titled "Introduction" he wrote for this translation, Neyyir claimed that "morality" should be the most important feature to be considered in choosing a novel for translation (See Endnote 7 and Appendix 6).

National customs were also significant for Osman Nuri who was one of the translators of Robenson. In his foreword titled "A Few Words", Nuri declared that he omitted some parts of the novel considering Turkish national customs and changed some other parts in accordance with the Turkish customs (1925: Foreword).

Ragıb Rıfkı, one of the most prolific translators of the Second Constitutional Period, adopted a stance that differed from the previous examples with respect to morality. In the foreword titled "Statement of Intention" he wrote for his translation of Delaforet's Paris Rezaletleri - Cellad Kadın (1331 [1915]), Rufkı stated that he did not omit the parts in the novel that were incongruous with morality since he believed that if people learned a lesson from these examples, Turkish morality could become even stronger. Even though his course of action was not similar to that of the previously mentioned translators, morality was still a point of emphasis for him (See Endnote 8 and Appendix 7). 
The Contribution of the Novels Translated into Ottoman Turkish Between the Ottoman Tanzimat Period and the Alphabet Reform to the Ottoman/Turkısh Cultural Heritage: An Overview of the Prefaces with a Focus on National Morals and Customs / A. Banu Karadă̆ (113-128. p.)

\subsection{Nationalism in Relation to Turkish Writers}

As mentioned previously, novel was a literary genre that entered the new Turkish culture and literature via translation. Besides translated novels, original novels were now being written, and in the course of time there began instances of Turkish writers being compared to Western writers. Halil Edib and Ali Riza, in their foreword titled "Our Statement" for their translation 13 Numaralh Araba (1307 [1889]), regarded European writers as masters. Turkish writers had covered a long distance by the year 1340 [1924]. In 1340 [1924], Cevad Sâmi translated Savuvalı Andre (1340 [1924]) by Paul de Kock and wrote a foreword for the translation where he compared a Turkish writer with the writer of the original work he had translated (See Endnote 9 and Appendix 8).

Tosun Paşa-zâde Mehmed Sedad, who translated Tolstoy's Zâlim Hükümdarlardan Car İvan Vasiliç' (n. d.), stated in his foreword that "Tolstoy is the Namık Kemal of Russia" (Trans. Tosun Paşa-zâde Mehmed Sedad (n. d.): Foreword).

One common literary activity in the historical period in question was writing short letters and notes of commendation where translators appreciated the translations of other translators. One example was the congratulations note written by Mahmud Esad for Halide Edib's translation Mâder (1314 [1896]) where he praised Halide Edib and Fatma Âliye Hanım, two woman translators of the period (See Endnote 10 and Appendix 9).

\subsection{Nationalism in Relation to National Resources}

One of the translators who provided detailed information on national resources in his forewords was Ali Haydar Taner who devoted his life to education and the Turkish youth. Taner translated two works by Grigory Petrov: Beyaz Zanbaklar Memleketinde (1928), Mefkûreci Muallim (1928). Both novels were indirect translations from the Bulgarian versions translated by D. Bojkov. The forewords he wrote for these two translations reveals the translator's aim to mobilize the Turkish nation, especially the Turkish youth. In his foreword titled "Translator's Introduction", he highlighted the importance of "awakening the sleeping souls, encouraging the youth to work for their people and homeland" (Trans. Ali Haydar [Taner] 1928: Foreword) and thus clearly expressed the skopos of his translations. In the very same foreword, the translator also suggested that the national land, forest and mining areas were yet "virgin" and exploiting them by means of the "scientific method" would enable the Turkish people to understand the abundance of their national resources. (Trans. Ali Haydar [Taner] 1928: Foreword).

\subsection{Nationalism in Relation to the Names of Protagonists and Themes}

Some of the translators decided to change not only the events but also the names of the persons and places in order to help the target audience to better understand the translations. Some translators opposed the strategy of giving Turkish names to the characters from other nations on the grounds that this created characters that would harm the good name of Turks and they explained the reasons for their decisions in the forewords. Süleyman Hurşid, who translated Krins. D. Smith's Hayvan Arkadaşlar (1927), was among the first group of translators. In the foreword titled "Translator's Introduction", Hurşid explained that he decided to change the original names of the persons and places in order to make the characters and places familiar for the target audience (See Endnote 11 and Appendix 10).

Ahmet Midhat Efendi, on the other hand, approached the issue of proper names from a different standpoint. In the foreword titled "Translator's Introduction" for his translation of Paul de Kock's Kamere Âşık (1303 [1885]), he stated that, because of the proper names, he pitied the time he had spent for reading a French novel which he had wanted to read thinking it was a novel about the East but disappointed to see that it was a novel which made Armenians 
Tanzimat'tan Harf Devrimine Kadar Osmanlı Türkçesine Çevrilen Romanların Kültürel Mirasımıza Katkısı: Millî Ahlâk ve Âdet Vurgusuyla Mukaddimelere Genel Bir Bakış / A. Banu Karadağ (113-128. s.)

look like Turks by giving Turkish names such as "Feride, Fatma" to Armenian women and based the Turkish-Islamic morality on these characters (See Endnote 12 and Appendix 11).

Some translators of the period also preferred to translate novels which were about the Turks in particular. In the foreword for his translation of Rus Ateşi (1926) by Paul Herigaut, Ahmed İhsan expressed his appreciation of the "love for Turks" in the novel which, in the view of the translator, portrayed the injustice and cruelty the Turks had suffered (See Endnote 13 and Appendix 12).

\section{Concluding Remarks}

To conclude, it is possible to argue that translated literature maintained a "central" position in the Turkish literary polysystem between the Tanzimat Period and the Alphabet Reform. During this period which was characterized by various attempts to modernize the Ottoman Empire, the literature in question "actively" shaped the "center" of the polysystem, and thus contributed to the "making" of a "new" culture repertoire which can not be considered "new" in nature, as a whole, as it revealed itself in full conformity with the Ottoman/Turkish morals and customs.

In terms of preliminary and operational norms, translators and/or publishers either viewed the content-related conformity as a criterion in selecting works for translation or they decided to change or omit the parts in the source texts that they considered inappropriate for the Ottoman/Turkish "national morals" (âdât-ı millî) and Islamic morals. While some translators were sensitive about the Turkish language, some others were specifically concerned about the material and spiritual characteristics of the Turks and the Turkish authors. To put it differently, the intrinsic role of translated novels in the establishment of a "new" national literary system during this period wasn't only determined by the innovative aspects of the Western novel as a literary genre, but also by its intrinsic dangers for the Ottoman/Turkish morals and customs: Westernization via the translation of Western novels through the filter of Islamization and/or Turkification. This "regularity of translation behaviour" refers to the set of established norms acquired by translators and publishers by implying some "sanctions" within the translated literary polysystem: both translators and publishers avoided to confuse good and bad for the Ottoman/Turkish readers and they spent great efforts to try to secure the territorial integrity of their national literary system against the "anti-national" and "anti-moral" literary movements from outer peripheric boundaries.

\section{Endnotes:}

1. "Geçenlerde tesadüfen gözüme ilişti: Muharrirlerimizden biri "fam dö şambrlık" terkibini kullanıyor. Bu zevk-şikenlik beni titretti, kızdırdı. Hâlâ da kızdırıyor. Fakat o zavallı muharrir de ne yapsın!. O tabiri "hizmetçi kız" diye mi tercüme etsin? Yine, o meramı ifade edemez.

Bu beladan kurtulmak için bir çaremiz vardır, lisanımızı tevsî‘ etmeliyiz. Arabîden, Fârısîden, kadim Türkçe kelimeler bularak, alarak tevsî́ etmeliyiz, o vahşi elfâz-ı ecnebiyeden ise daima tevakkî eylemeliyiz" (Trans. Ali Kemâl 1330 [1914]: Foreword).

2. "Arapça fesîh olduğu kadar bize mûnistir. Arapça bir kelime Türkçemize müfîd, müessir bir tarzda girerse revnak verir. Kudret verir. Zarar vermez. Acemce de böyledir. Hatta biz bu iki lügât-i garrâyı bazı nev-zuhurlarımızın yapmak istedikleri gibi o kadim Türkçeye feda etmek taraftarı değiliz. O taassubu tecvîz etmeyiz. Lisân-ı muhteşem-i Osmânîyi o derekeye indirmek, o maziye ircâ‘a kalkışmak vahşettir. Mesela Fuzulilerin, Bakilerin, Nefilerin, hele Nedimlerin o tarz-ı mu'ciz-i beyânını bir tarafa atarak Türkçe şiirler dedikleri o zavallı, o güdük ifâde-i 'acîbeye ibtilâ göstermek hakikatte milletimize, Osmanlılı̆̆ımıza ihanettir.. Bütün hazâin-i edebîmize suikasddir.

\section{Osmanlı lisanı bu lisandır}

Fikreyle ne bahr-i bî-kerândır! 
The Contribution of the Novels Translated into Ottoman Turkish Between the Ottoman Tanzimat Period and the Alphabet Reform to the Ottoman/Turkısh Cultural Heritage: An Overview of the Prefaces with a Focus on National Morals and Customs / A. Banu Karadağ (113-128. p.)

diye iftihar eden üstâze-i edîbimiz böyle bir gafletimizi, hoppalığımızı görselerdi ne derlerdi!" (Trans. Ali Kemâl 1330 [1914]: Foreword).

3. "Hâsılı bir gün arkadaşlarımdan, sevdiklerimden biri bir efrenc-pesendî: 'Türkçeyi hâlâ öğrenemedim, öğrenmek de istemem.. Ne karışık şey..’ dedi.. Bir Türk’ün ağzından çıkan bu söz yüreğime ok gibi saplandı.. Biri size: 'Anne nedir, ne demektir, hâlâ anlayamadım, anlamak da istemem, ne tuhaf șey..' dese ne hâle gelirsiniz? Hâlbuki esasen şu iki küfrün mahiyeti birdir. Lisan da bîr fikr-i sâf için, bir vicdân-ı hakîkî için anne kadar, baba kadar, vatan kadar muazzezdir" (Trans. Ali Kemâl 1315 [1897]: Foreword).

4. "Şunun tercümesi hevesine düş̧ük. Fakat bizce tercüme hususundaki mesleğimiz de kâri’lerimizin malumudur ya? Bazı mütercimlerin tercümeleri lisân-ı letâfet-resân-ı Osmânîmizi şivesinden düşürecek soğuk bir hâle koyacak surette olduğu hâlde Ahmed Midhat'ın tercümesini güya asıl Osmanlıca yazılmış kadar şive-i letâfet-i Osmâniyemize muvafik bulanlara vaktiyle ihtar eylemisstik ki biz tercüme-i ayniye taraftarı değiliz. Fransızca bir cümleyi bir kelamı hatta bir sahifeyi okuruz. Ne anlar isek onu müstakilen yani yeniden Osmanlıca yazarız. İşte bunun için bizim tercümelerimiz re'sen Osmanlıca yazılmış gibi olur” (Trans. Ahmed Midhat Efendi 1306 [1888]: Foreword).

5. "Vâkıa ahlâk-ı İslâmiyeyi ihlal edecek yahud 'âdât-ı kavmiyemize mugâyir gelecek yani bize bütün bütün ecnebi görünecek zeminler üzerine bina edilmiş sair Frenk romanları dediğimiz mahzurlara nispet onların âdât ve efkârına vukuf hâsıl etmek gibi bizce pek büyük ehemmiyeti haiz olamayacak olan fâideden başka netice gösteremeyeceği cihetle intihâb sırasında fennî romanlara nispet pek geri kalır" (Trans. Ahmed İhsan 1308 [1890]: Foreword).

6. "İște (Jül Vern)in eserleri de fennin mühim bir mebhasini şârih olduğu, milel-i sâirenin ma'âyib-i ahlâkiyesini âdât-ı zemîmesini nakletmek gibi mündericât-ı muzırreden azade bulunduğu için, efkâr-ı Osmâniyeyi tenvir etmeye başlayan meyl-i ciddiyât tarafindan, fevkalâde bir rağbetle telakki olunmuştur. Hele tercümesine şürû́ ettiğimiz şu \{Arzdan Kamere Seyahat\} romanı bu nokta-i nazardan (Jül Vern)in diğer eserlerine de faiktir.

Bu cihetle Fransa Akademisi tarafından bilhassa nâil-i takdîr ü tahsîn olmuş ve ekseri lisanlara tercüme edilerek rağbet-i fevkalâde kazanmıştır. Hatta elimizdeki nüshası yirmi sekizinci tab‘idır” (Trans. Mazhar 1309 [1881]: Foreword).

7. "Şu kadar ki tercüme edilecek kitapta aranılacak şartlardan biri de ve belki de en mühimi o kitabın mündericâtının aklen ve hikmeten makbul olması ve alelhusus bizim ahlak ve âdâtımıza tevafuk etmesidir yoksa şu şeraiti haiz olmayan bir kitabın tercümesi menfaati değil bilakis mazarratı mûcib olur şu hâle nazaran emr-i intihâbın bir dikkat-i fevkalâde dairesinden geçirilmesi lazım gelir” (Trans. Yusuf Neyyir 1296 [1878]: Foreword).

8. “Terbiyeyi terbiyesizlerden öğrendim” kelâm-ı hikmet-âmîzi mâdâmü’z-zamân payidar bir düstûr-1 hakîkat olduğundan kitabımızda görülecek zemâim-i medeniye sahneleri de bizde ahlâk-ı millînin daha ziyade metanetleşmesi için bir ders-i intibâh olacaktır. Maksadımızı tamamıla ihtiva eden bir kelime varsa o da ibrettir" (Müt. Ragıb Rıfkı 1331 [1915]. Ön söz).

9. "Kâri'lerini kahkahalarla güldürürken aynı zamanda ağlatmak gibi iki zıt hâssayı şahsında cem etmiş bir muharrire her asırda nadir tesadüf olunduğu için bu kabîl zevâtın mensup oldukları millet nazarında pâyeleri pek bülend olmak lâzım gelir. Bizde bu pâye-i bülendi ihrâz emiş bir tek ferd vardır ki o da üstâd-ı muhterem Hüseyin Rahmi Beyefendi'dir. Hüseyin Rahmi Beyefendi Türkiye'de bizim için nasıl muhterem bir şahsiyet ise (Pol dö Kok) da Fransa'da hatta bütün Avrupa'da o derece hâiz-i şöhret ve itibar bir müelliftir” (Trans. Cevad Sâmi 1340 [1924]: Foreword). 
Tanzimat’tan Harf Devrimine Kadar Osmanlı Türkçesine Çevrilen Romanların Kültürel Mirasımıza Katkısı: Millî Ahlâk ve Âdet Vurgusuyla Mukaddimelere Genel Bir Bakış / A. Banu Karadă̆ (113-128. s.)

10. “...yirmi senelik bir zaman zarfında âsârını değil Osmanlılara, Avrupalılara bile tanıttıracak nice fâzılât-ı nisvân yetişmiştir. Bundan yirmi otuz sene ever biri çıııp da yirmi sene sonra ismetli Fatma Aliye Hanımefendi gibi bir fâzıla-i Osmâniye yetişeceğini ve yazdığı eserin Fransız, İngiliz, Arap lisanlarına da kemâl-i takdîr ile nakledileceğini söyleseydi inanamazdık. Ve keza yirmi sene sonra sizin gibi bir nev-nihâl-i 'irfânın terbiye-i mâderâneye dair İngilizce en mühim, en muteber bir eseri lisanımıza tercüme edeceğini haber verseydi doğrusu buna da ihtimal veremez idik" (1314 [1896]: Foreword).

11. "Hikâyelerin aslındaki ecnebi isimlerin yekdiğerinden az çok güçlükle tefrîk edilebileceği ve hayvanlar ile insanlara Türk ismi verilirse hikâyeler, bu tercümenin kâri'lerini daha yakından alâkadar edeceği mülâhazasıyla, ekser ecnebi isimleri yerine (şehir ve semt isimlerine varıncaya kadar) Türk isimleri ikâme etmek daha muvafik görülmüştür. Mütercim tarafından dahi nihayete bir iki hikâye ilave edilmiştir” (Trans. Süleyman Hurşid 1927: Foreword).

12. "Jul Mari isminde yeni bir müellifin "Markiz Gabriyel" nâmında bir romanı ki evvela Levant Heralde saniyen Monitor Oryantal gazetesine tefrika edilip fazla olarak bir Rum gazetesine dahi tefrika edileceğini işittiğim için pek meşhur bir şey zannederek okumuştum. Hele işin bir ciheti dahi Şark'a ait olmasını pek muvafik bulmuş idim. Bir de okuyayım ki, Ermeni kadınlarının ismini Feride ve Fatma tesmiye etmek ve Ermenileri asıl Türk zannederek ahlâk-ı Osmâniye ve İslâmiyeyi bunlara isnat eylemek gibi azim hatîâtla pek cahilane yazılmış bir şeymiş. Zahmetime de acıdım” (Trans. Ahmed Mithat 1303 [1885]: Foreword).

13. “... kadın kahraman, Rus İhtilali'nde Odesa ve Sivastopol'den buraya akıp dökülen Moskof kadınlarından birisidir. Bu ikisinin arasında cereyan eden vaka İtilaf Devletleri'nin ve onların gizli polislerinin İstanbul'da yaptıkları melanetleri, kullandıkları vasıtaları yakından görmüş bir nazarla tasvir ediliyor. Muharrir, İstanbul'da geçirdiği işgal senelerinde Türkleri iyi anlamış olacak ki romanda açık bir Türk muhibliği devam eder. Sonra hiç şüphe yok ki Pol Herigo içine karıştığı vakalar arasında çıplak hakikatlerden romanını yazmış, sade Türkleri sevmiş değil, Beyoğlu muhitinin, levanten güruhunun, ikiyüzlü Rumların ruhunu da iyi anlamıştır" (Trans. Ahmed İhsan 1926: Foreword).

\section{References}

Abbot, J. (1314 [1896]). Mâder. Müt. Halide Edib [Adıvar]. İstanbul: Karabet Matbaası.

Andı, F. (1999). Roman ve Hayat. İstanbul: Kitabevi.

Bozkurt, E. (2014). 1908-1928 Yılları Arasında Batı Dillerinden Osmanlı Türkçesine Çevrilen Romanlarda Mukaddime Geleneği. Doktora Tezi. İstanbul: Yıldız Teknik Üniversitesi Sosyal Bilimler Enstitüsü.

Defoe, D. (1925). Robenson. Müt. Osman Nuri. Varna: İleri Matbaa.

Delaforet, D. (1331 [1915]). Paris Rezaletleri - Cellad Kadın. Müt. Ragıb Rıfkı [Özgürel]. İstanbul: Şems Matbaası.

Even-Zohar, I. (2002). The Making of Culture Repertoire and The Role of Transfer. Translations: (Re)Shaping of Literature and Culture (Ed. Saliha Paker). İstanbul: Boğaziçi Üniversitesi Yayınları. 166-174.

Feuillet, O. (1298 [1880]). Bir Fakir Delikanlının Hikâyesi. Müt. Ahmed Midhat. İstanbul: Tercüman-ı Hakikat Matbaası.

Herigaut, P. (1926). Rus Ateşi. Müt. Ahmed İhsan [Tokgöz]. İstanbul: Ahmed İhsan Matbaası. 
The Contribution of the Novels Translated into Ottoman Turkish Between the Ottoman Tanzimat Period and the Alphabet Reform to the Ottoman/Turkssh Cultural Heritage: An Overview of the Prefaces with a Focus on National Morals and Customs / A. Banu Karadağ (113-128. p.)

Karadağ, A. B. (2014a). Çevirmenin Tanıklı̆ında Tanzimat'tan II. Meşrutiyet'e Çeviri Tarihini Yeniden Okumak. C. 1. İstanbul: Diye Yayınları.

Karadağ, A. B. (2014b). Çevirmenin Tanıkh̆̆ında Tanzimat'tan II. Meşrutiyet'e Çeviri Tarihini Yeniden Okumak. C. 2. İstanbul: Diye Yayınları.

Kock, P. de (1303 [1885]). Kamere Âşık. Müt. Ahmed Midhat. İstanbul: Tercüman-ı Hakikat Matbaasi.

Kock, P. de (1340 [1924]). Savuvalı Andre. Müt. Cevad Sâmi. İzmir: Ahenk Matbaası.

Lamartine. (1296 [1878]). Graziella. Müt. Yusuf Neyyir. İstanbul: Kırk Anbar Matbaası.

Lamartine. (1316 [1898]). Rafael. Müt. Müstecabi-zade İsmet - İskender Ferari. İstanbul: Tahir Bey Matbaası.

Montépin, X. (1307 [1889]). 13 Numaral Araba. Müt. Halil Edib - Ali Rıza. İstanbul: Mahmud Bey Matbaası.

Ohnet, G. (1305 [1887]). Son Aşk. Müt. Bogos. İstanbul: Karabet Matbaası.

Petrov, G. (1928). Beyaz Zanbaklar Memleketinde. Müt. Ali Haydar [Taner]. İstanbul: Marifet Matbaasi.

Petrov, G. (1928). Mefkûreci Muallim. Müt. Ali Haydar [Taner]. İstanbul: Marifet Matbaası.

Prévost, M. (1315 [1897]). Jülyet’in İzdivacı. Müt. Ali Kemal. İstanbul: Tahir Bey Matbaası.

Prévost, M. (1330 [1914]). Yeni Kadın Mektupları. Müt. Ali Kemal. İstanbul: Tevsi-i Tıbaat Matbaasi.

Sevük, İ. H. (1940). Avrupa Edebiyat ve Biz: Garpten Tercümeler. C. 1. İstanbul: Remzi Kitabevi.

Sevük, İ. H. (1941). Avrupa Edebiyatı ve Biz: Garpten Tercümeler. C. 2. İstanbul: Remzi Kitabevi.

Smith, G. (1927). Hayvan Arkadaşlar. Müt. Süleyman Hurşid. İstanbul.

Tolstoy, L. (No date). Zalim Hükümdarlardan Çar İvan Vasiliç. Müt. Mehmed Sedad. İstanbul: Sancakciyan Matbaası.

Toury, G. (1995). Descriptive Translation Studies and Beyond. Amsterdam-Philadelphia: John Benjamins Publishing Company.

Türkeli, Y. (2005). Tanzimat’tan Sonra Türkçede Roman Tercümeleri (1860-1928). Yüksek Lisans Tezi. Fatih Üniversitesi Sosyal Bilimler Enstitüsü.

Verne, J. (1308 [1890]). Yeraltında Seyahat. Müt. Ahmed İhsan [Tokgöz]. İstanbul: Âlem Matbaasi.

Verne, J. (1309 [1891]). Arzdan Kamere Seyahat. Müt. Mazhar. İstanbul: Mekteb-i Sanayi Matbaasi.

\section{Appendices:}


RumeliDE Dil ve Edebiyat Araştırmaları Dergisi 2015.2 (Nisan)/ 123

Tanzimat’tan Harf Devrimine Kadar Osmanlı Türkçesine Çevrilen Romanların Kültürel Mirasımıza Katkısı: Millî Ahlâk ve Âdet Vurgusuyla Mukaddimelere Genel Bir Bakış / A. Banu Karadağ (113-128. s.)

\section{Appendix 1:}

\section{Yeni Kadin Mektuplarn}
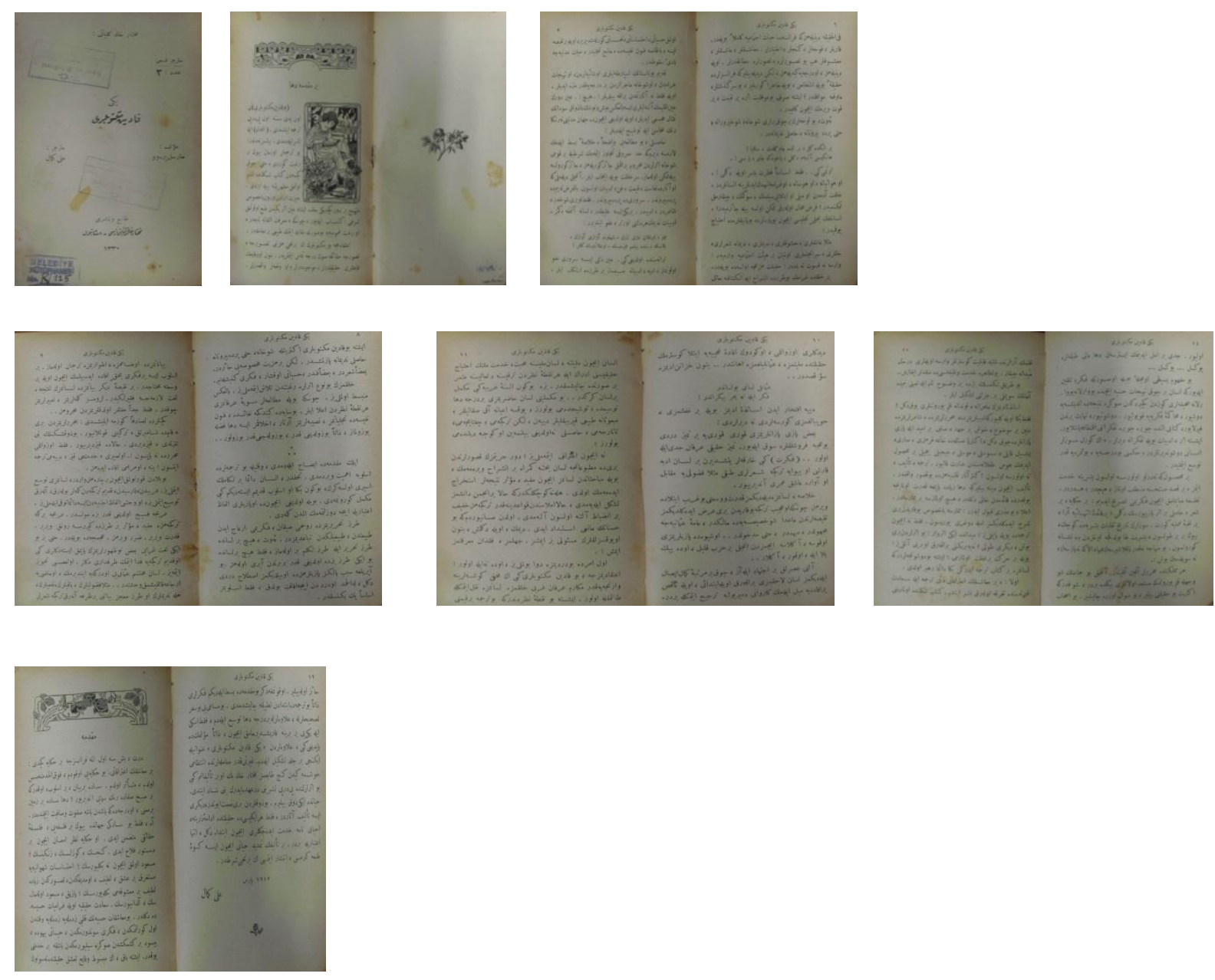

\section{Appendix 2:}

\section{Jülyet'in İzdivace}
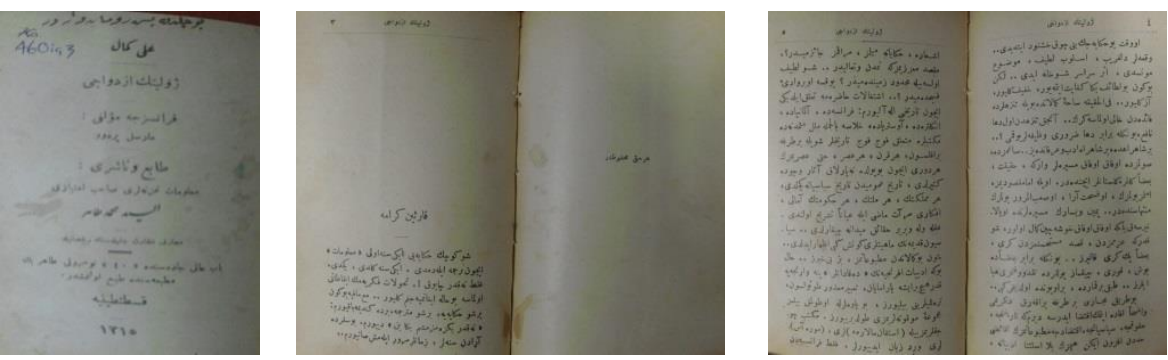
RumeliDE Journal of Language and Literature Studies 2015.2 (April)/ 124

The Contribution of the Novels Translated into Ottoman Turkish Between the Ottoman Tanzimat Period and the Alphabet Reform to the Ottoman/Turkısh Cultural Heritage: An Overview of the Prefaces with a Focus on National Morals and Customs / A. Banu Karadağ (113-128. p.)
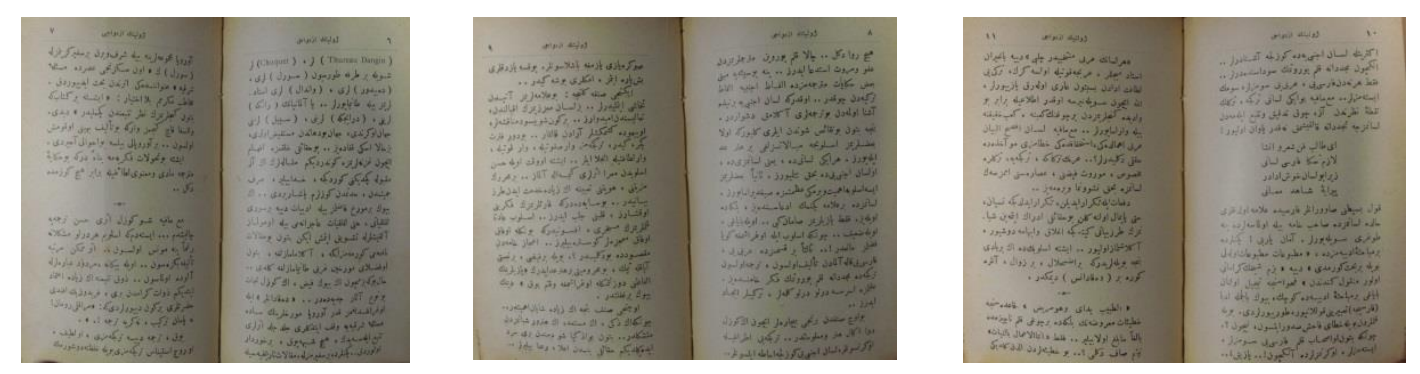

\section{Appendix 3:}

\section{Bir Fakir Delikanlınm Hikâyesi}
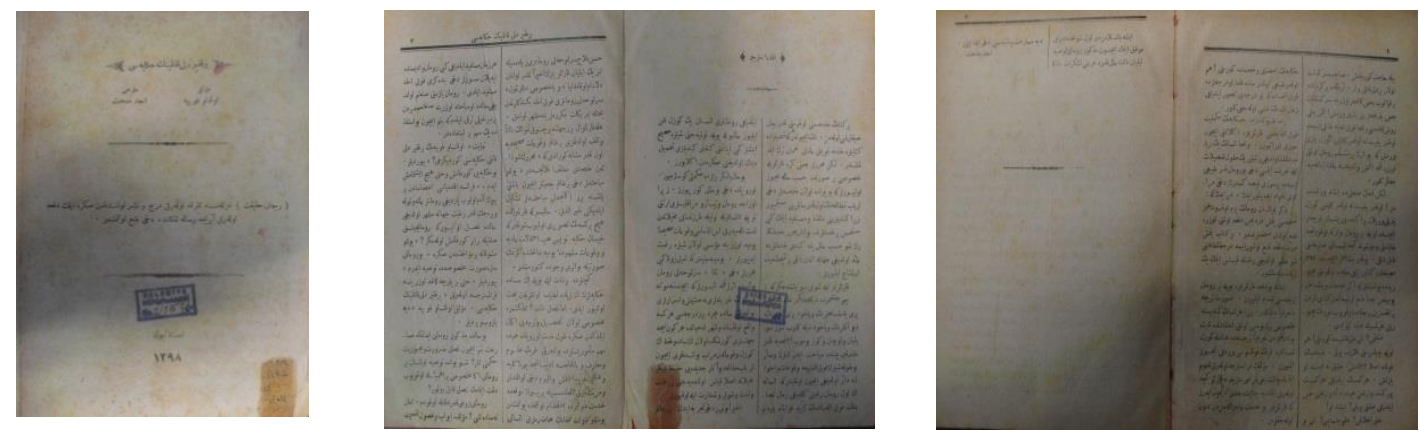

\section{Appendix 4:}

\section{Yeraltonda Seyahat}
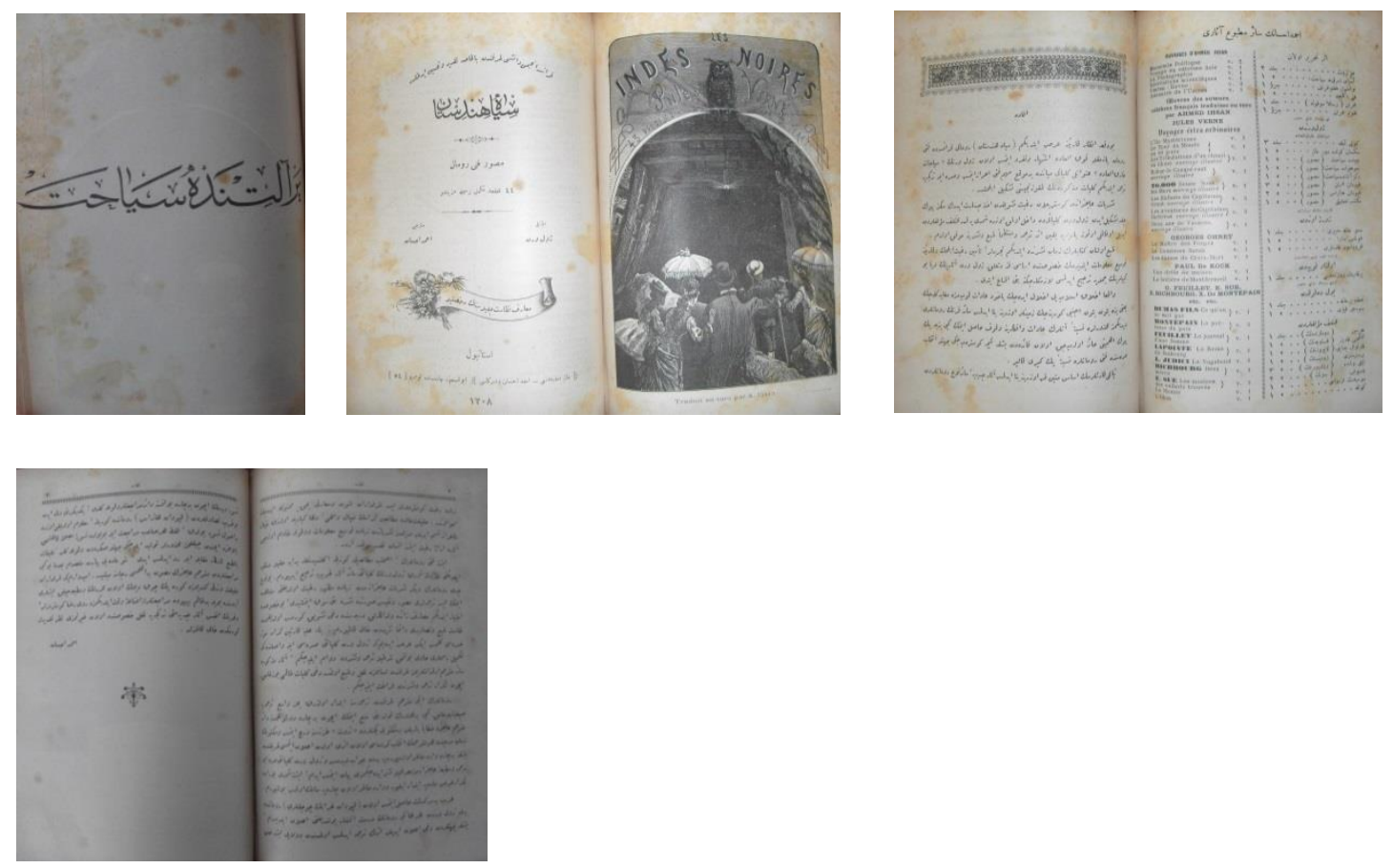
Tanzimat’tan Harf Devrimine Kadar Osmanlı Türkçesine Çevrilen Romanların Kültürel Mirasımıza Katkısı: Millî Ahlâk ve Âdet Vurgusuyla Mukaddimelere Genel Bir Bakış / A. Banu Karadağ (113-128. s.)

\section{Appendix 5:}

\section{Arzdan Kamere Seyahat}
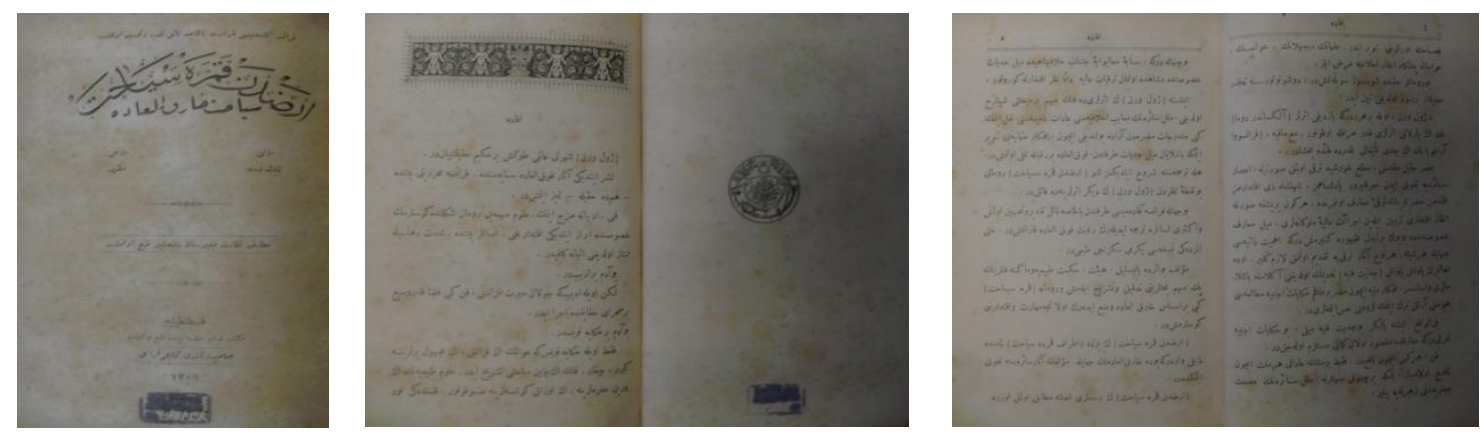

\section{Appendix 6:}

\section{Graziella}
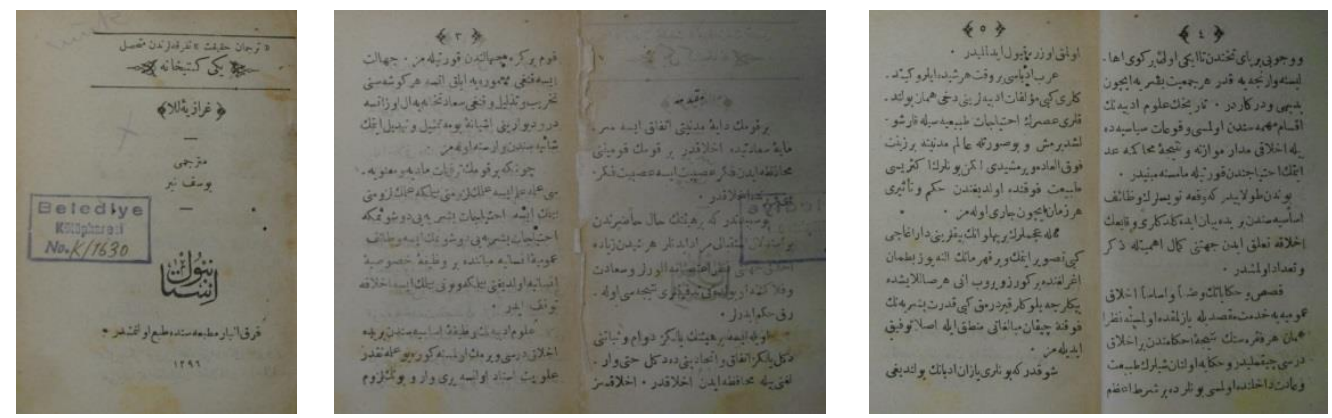

\section{Appendix 7:}

\section{Paris Rezaletleri - Cellad Kadon}
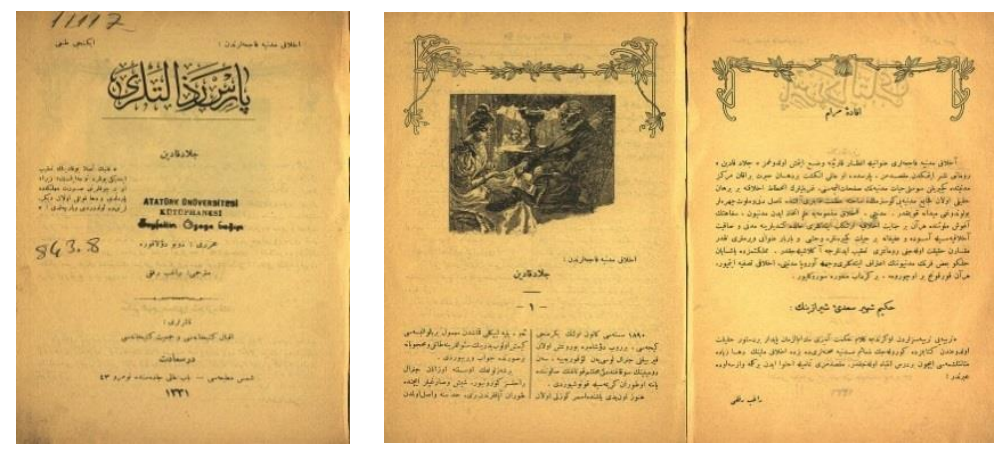
The Contribution of the Novels Translated into Ottoman Turkish Between the Ottoman Tanzimat Period and the Alphabet Reform to the Ottoman/Turkısh Cultural Heritage: An Overview of the Prefaces with a Focus on National Morals and Customs / A. Banu Karadağ (113-128. p.)

\section{Appendix 8:}

\section{Savuvali Andre}
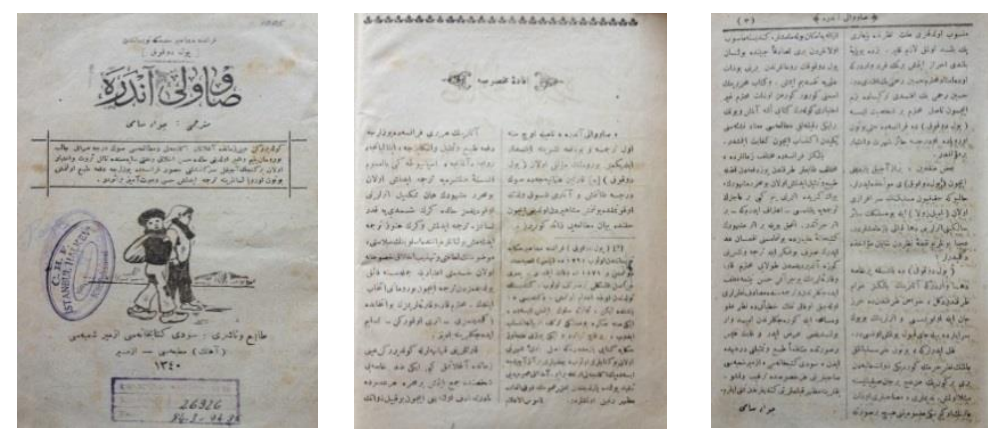

\section{Appendix 9:}

\section{Mader}
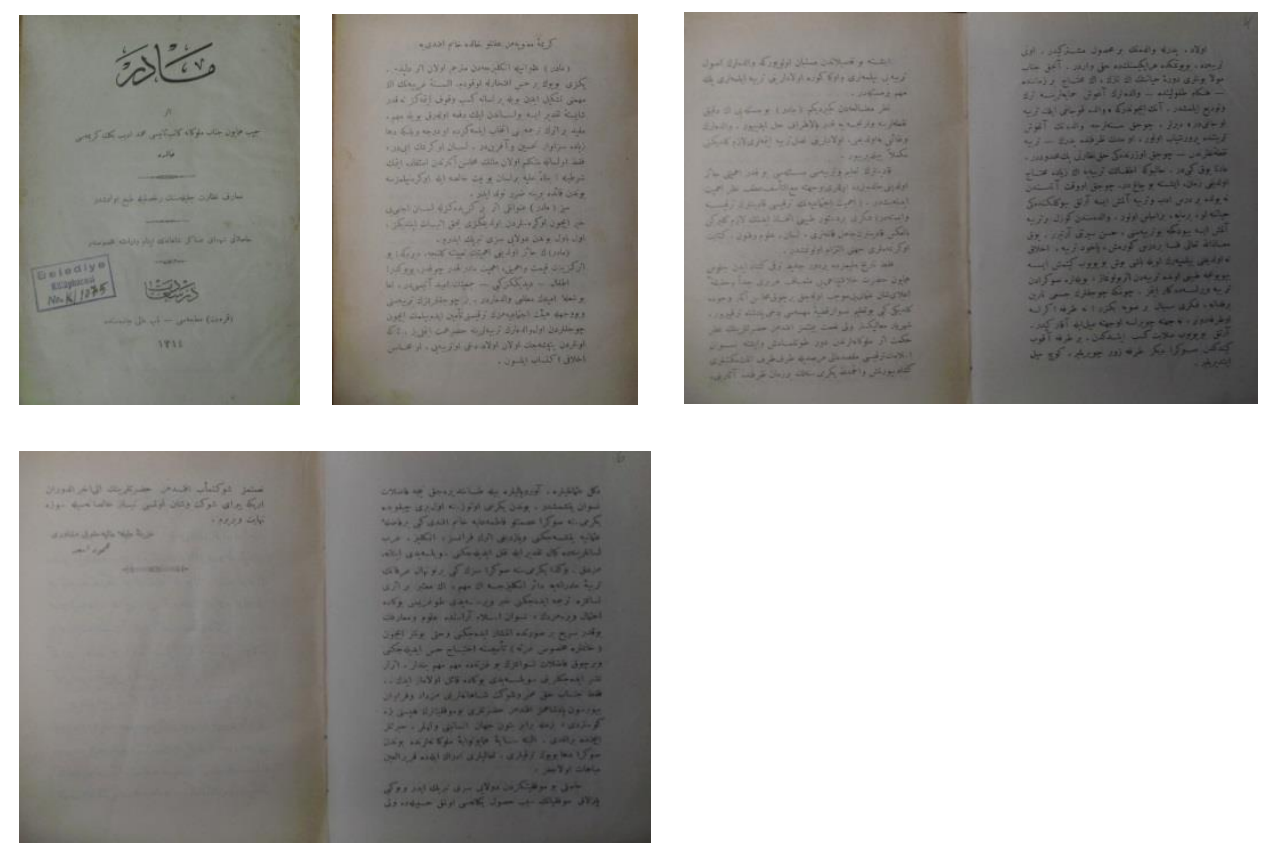

\section{Appendix 10:}

\section{Hayvan Arkadaşlar}


RumeliDE Dil ve Edebiyat Araştırmaları Dergisi 2015.2 (Nisan)/ 127

Tanzimat’tan Harf Devrimine Kadar Osmanlı Türkçesine Çevrilen Romanların Kültürel Mirasımıza Katkısı: Millı̂ Ahlâk ve Âdet Vurgusuyla Mukaddimelere Genel Bir Bakış / A. Banu Karadağ (113-128. s.)
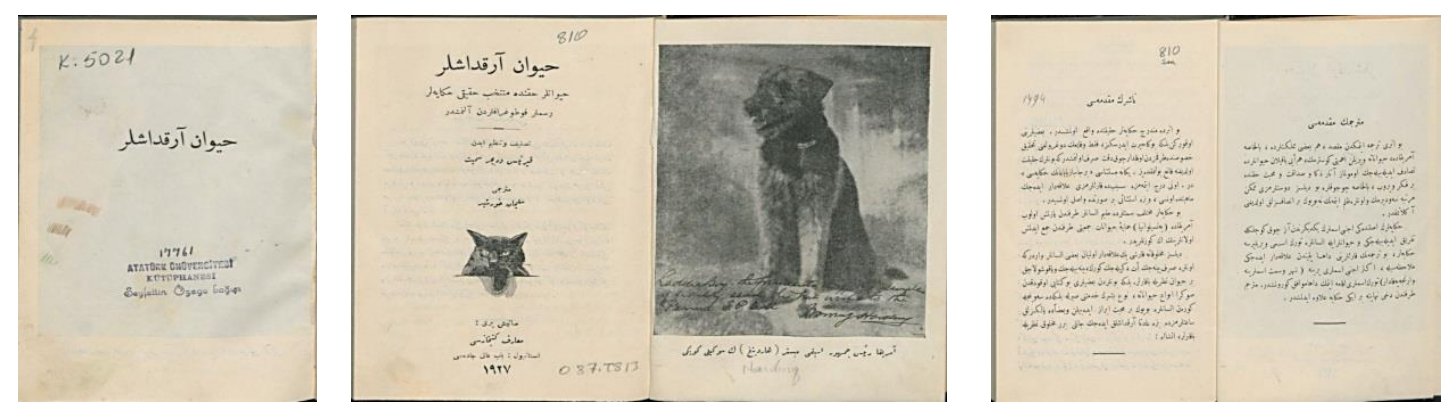

\section{Appendix 11:}

Kamere Âşık
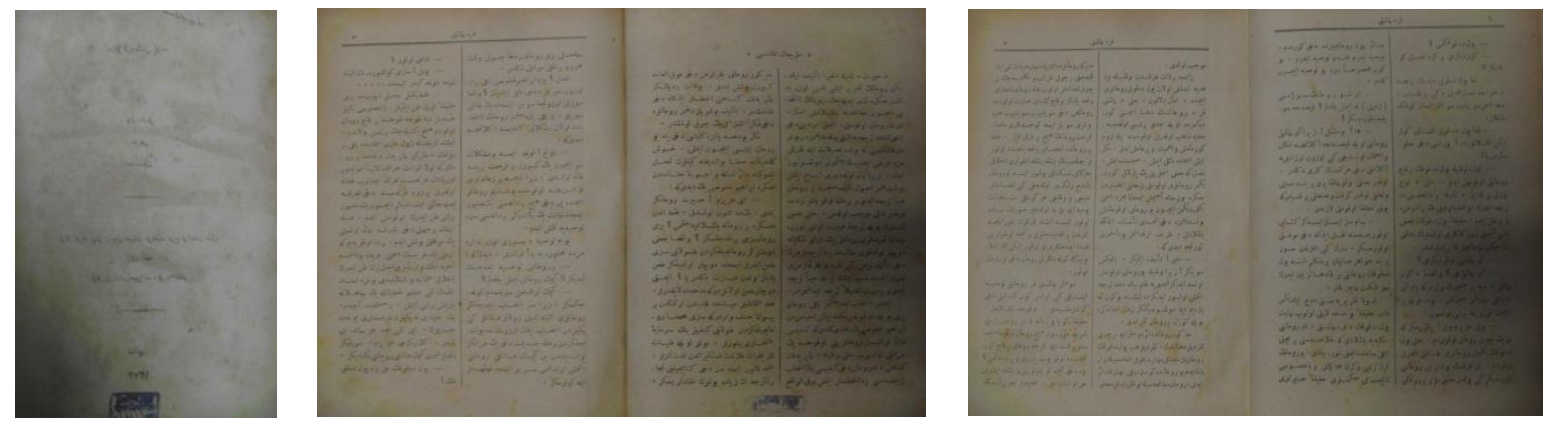

\section{Appendix 12:}

\section{Rus Ateşi}
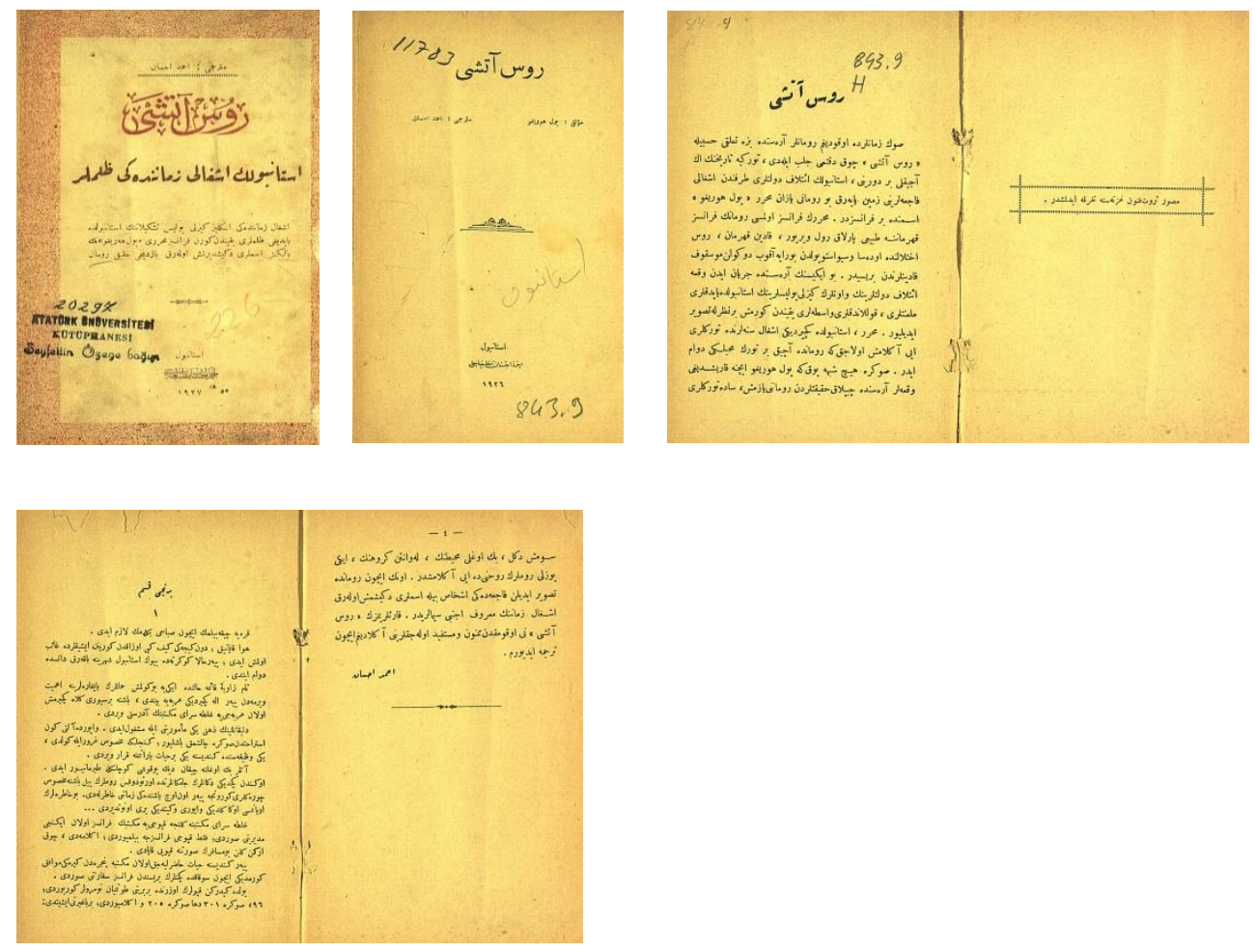
RumeliDE Journal of Language and Literature Studies 2015.2 (April)/ 128

The Contribution of the Novels Translated into Ottoman Turkish Between the Ottoman Tanzimat Period and the Alphabet Reform to the Ottoman/Turkssh Cultural Heritage: An Overview of the Prefaces with a Focus on National Morals and Customs / A. Banu Karadağ (113-128. p.) 